\title{
INOVASI MESIN PENGOLAHAN PAKAN DENGAN KONSENTRAT LIMBAH CANGKANG TELUR DAN KEONG SAWAH
}

\author{
Junil Adri ${ }^{1}$, Bulkia Rahim ${ }^{2}$ dan Nelvi Erizon ${ }^{3}$ \\ ${ }^{1,2,3}$ Fakultas Teknik, Universitas Negeri Padang, Jl. Prof. Dr. Hamka Air Tawar Barat \\ email: juniladri@ft.unp.ac.id
}

\begin{abstract}
Abstrak: Rancangan mesin pengolahan limbah cangkang telur dan keong sawah ini dilatar belakangi oleh hasil observasi dan studi literatur, dimana para peternak ayam sering memodifikasi pakan 511 dengan tambahan tumbukan tulang ikan dan batu kapur. Khususnya untuk pakan tambahan, belum adanya mesin untuk mengolah pakan tambahan seperti limbah cangkang telur dan keong sawah. Perancangan mesin ini dilakukan untuk membuat pakan ayam berupa ransum berbentuk serbuk, halus dan kasar juga menghitung kapasitas produksi dari mesin. Hasil rancangan mesin pencetak pakan dengan menggunakan mekanisme screw dengan daya motor penggerak $1 \mathrm{HP}$ dengan rotasi $2800 \mathrm{rpm}$ dan reducer dengan konversi putaran 1:30. Selain itu, mesin ini juga menggunakan diskmild sebagai penghancur dari konsetrat yang digunakan. Diskmild digerakan dengan menggunakan motor yang sama. Sehingga motor yang digunakan ini menggerakkan dua buah mesin sekaligus. Kapasitas uji kinerja mesin pengolahan cangkang telur dan keong sawah sehingga terbentuknya ransum sebesar $15,86 \mathrm{~kg} / \mathrm{jam}$ dan persentase bahan yang tidak tercetak yaitu $8 \%$. Hasil ransum yang berbentuk serbuk yang dihasilkan dengan bahan baku awal $1 \mathrm{~kg}$ adalah $0,2323 \mathrm{~kg}$, ransum yang berbentuk halus adalah $0,3749 \mathrm{~kg}$, dan ransum yang berbentuk kasar adalah $0,3128 \mathrm{~kg}$.
\end{abstract}

Kata Kunci: Rancangan Mesin, Cangkang Telur, Keong Sawah, Pakan Ayam.

Abstract: The design of the eggshell and rice snail waste processing machine is motivated by observations and literature studies, where chicken farmers often modify the 511 feed with the addition of fish bone and limestone collisions. Especially for additional feed, there is no machine to process additional feed such as eggshell waste and rice conch. The design of this machine is done to make chicken feed in the form of powder, fine and coarse ration also calculating the production capacity of the machine. The results of the design of the feed printing machine using a screw mechanism with driving power of $1 \mathrm{HP}$ with $2800 \mathrm{rpm}$ rotation and reducer with 1:30 rotation conversion. In addition, this machine also uses diskmild as a destroyer of concentrates used. Diskmild is driven using the same motor. So that the motor used is moving two engines at once. Test capacity of the performance of eggshell and rice conch processing machines so that the ration formation is $15.86 \mathrm{~kg} /$ hour and the percentage of the material that is not printed is $8 \%$. The results of rations in the form of powder produced with an initial raw material of $1 \mathrm{~kg}$ are $0.2323 \mathrm{~kg}$, the fine ration is $0.3749 \mathrm{~kg}$, and the ration in the rough form is $0.3128 \mathrm{~kg}$.

Keywords: Machine Design, Eggshell, Rice Conch, Chicken Feed.

\section{PENDAHULUAN}

Sektor perternakan merupakan sektor strategis yang harus dipertimbangkan. Peternakan ayam merupakan salah satu sektor yang penting dalam memenuhi kebutuhan manusia akan protein hewani, ini ditandai dengan peningkatan produksi daging dan telur ayam yang sangat pesat dari tahun ke tahun. Produksi daging ayam nasional tahun 2016 mencapai 1.895 .000 ton dan telur 1.683.000 ton. Sementara itu untuk Provinsi Sumatera Barat tercatat sebesar 63.603 ton daging dan telur sebesar 78.491 ton. Sedangkan di Kota Payakumbuh tahun 2016 produksi daging ayam broiler 3.544 ton dan produksi telur 6.498 ton (http://sdp2d.sumbarprov.go.id)

Ternak ayam merupakan komuditas peternakan yang paling banyak dipelihara 
oleh petani-peternak di pedesaan. Produk komuditas peternakan ini adalah sumber protein hewani yang dapat dijangkau oleh lapisan masyarakat secara luas. Sejarah dengan meningkatnya jumlah penduduk, perubahan gaya hidup, kesadaran gizi, dan perbaikan tingkat pendidikan, permintaan produk peternakan (telur, daging, dan susu) terus meningkat. Pada tahun 2035 diperkirakan penduduk Indonesia akan meningkat dua kali lipat jumlahnya menjadi \pm 400 juta jiwa. Indonesia memerlukan tambahan ketersediaan bahan pangan lebih dari dua kali lipat dari kebutuhan saat ini, termasuk ketersediaan telur ayam. Beberapa usaha diperlukan untuk meningkatkan populasi dan produktifitas ayam petelur. Produktifitas ayam petelur dapat ditingkatkan diantaranya dengan memperbaiki manajemen pemeliharaan, pakan, pencegahan, dan penanggulangan penyakit. Usaha peternakan ayam pedaging dan petelur semakin banyak berkembang sesuai dengan kebutuhan masyarakat. Perkembangan bidang peternakan ini tentunya memberikan dampak pada penyediaan pakan dan kualitas gizi pada pakan ternak.

Penulis selaku ketua peneliti memiliki pengalam beternak ayam pedaging dan ayam kampung. Untuk memenuhi kebutuhan gizi ayam peneliti pernah melakukan berbagai cara, salah satunya dengan menumbuk daging keong sawah dan dicampur dengan dedak. Dalam pengamatan peneliti ayam menyukai bentuk pakan ini, selain itu pertumbuhan ayam juga terlihat semakin cepat. Untuk penggunaan cangkang telur, peneliti melihat fenomena para peternak ayam peterlur yang mana mereka memodifikasi pakan 511 dengan tambahan tunbukan tulang ikan dan batu kapur. Guna penambahan konsentrat ini guna mempercepat pengerasan cangkang telur yang dihasilkan ayam. Dari pengalaman ini penulis mencoba mensiasati penggunaan tumbukan tulang ikan di ganti dengan cangkang telur. Limbah cangkang telur selama ini hanya terbuang begitu saja. Sangat banyak gerai nasi goreng, kafe, pabrik kue dan rumah makan hnaya membuang limbah cangkang telur dengan begitu saja. Kandungan dari cangkang telur cukup banyak, diantara nya posfor, magnesium dan kalsium dan ini baik untuk pertumbuhan ayam.

Melalui penelitian ini peneliti akan mengembangkan kualitas pakan ayam dengan menambahkan pengolahan limbah cangkang telur dan keong sawah. Penulis merencakan mesin penunjang proses pengolahan pakan. Mesin yang dirancang akan memudahkan dalam proses produksi pakan. Peneliti menginginkan penelitian ini sampai pada tahap pengembangan dan pemasaran produk pakan ternak.

Penelitian ini bertujuan untuk menghasilkan mesin pengolah pakan ternak yang bernilai gizi tinggi dengan mengkombinasikan limbah cangkang telur dan keong sawah dalam pakan ternak. Pakan ternak ini diharapkan dapat meningkatkan produktivitas peternakan yang ada di Indonesia. Peneliti merancang mesin mengolah limbah cangkang telur dan keong sawah sehingga dapat digunakan sebagai pakan ternak. Mesin yang dirancang bersifat efisien dan praktis sehingga diharapkan setiap peternak dengan mudah memilikinya.

Mesin yang dibuat dalam penelitian ini memiliki ayakan yang akan berfungsi sebagai pemisah antara pakan ayam yang dapat digunakan untuk pakan anakan ayam dan pakan ayam yang sudah besar. Ayakan terdiri dari tiga tingkatan. Tingkatan paling bawah akan menghasilkan pakan yang sangat halus yang akan digunakan untuk pakan anakan ayak yang berumur 1 hari 10 hari. Untuk ayakan tingkat 2 akan menghasilkan pakan yang berbentuk butiran-butiran kecil, biasa ukuran ini digunakan untuk pakan ayam umur 10-15 hari dan ayakan pada tingkatan 3 akan menghasilkan pakan berbentuk butiran. Pakan ini digunakan untuk ayam yang sudah besar, baik untuk ayam pedaging ataupun ayam petelur. 
Peneliti melihat realita bahwa limbah bila dapat didaur ulang maka akan menciptakan nilai tambah baru dengan keuntungan timbal-balik. Limbah cangkang telur sangat mudah ditemukan karena setiap kafe, pabrik kue, rumah makan dan setiap orang pasti menghasilkan limbah ini. Sementara kandungan dari cangkang telur ini masih bisa manfaatkan. Disisilain keong sawah selama ini hanya menjadi hama bagi para petani. Nilai kandungan protein dari keong sawah ini sangat tinggi. Dengan dimanfaatkan keong sawah ini para petani akan terbantu karena hamanya dijauhkan dari sawah dan dijadi pakan ternak.

Manfaat lain yang diharapkan dari penilitian ini adalah adanya alat pengolah pakan ternak dan bentuk pakan ternak yang baru, yang mana pakan ternak yang dimaksudkan dalam penlitian ini adalah pakan ternak yang memanfaatkan limbah cangkang telur dan keong emas yang diolah menjadi pakan ternak yang bernilai gizi tinggi.

Pakan adalah campuran berbagai macam bahan organik yang diberikan kepada ternak termasuk memnuhi kebutuhan zat-zat makanan yang diperlukan bagi pertumbuhan, perkembangan dan reproduksi. Agar pertumbuhan dan produksi maksimal, jumlah dan kandungan zat-zat makanan yang diperlukan ternak harus memadai. (Suprijatna:2008).

Bahan pakan konvensional yang sering digunakan dalam pakan, biasanya mempunyai kandungan nutrisi yang cukup (protein) dan disukai ternak. Bahan baku konvensional merupakan bahan makro, serta jagung, kedelai, gandum, tepung ikan dan bahn lainnya. Bahan baku subtitusi merupakan bahan baku yang berasal dari bahan yang belum banyak dimanfaatkan sebagai bahan dari hasil ikatan industri agro atau peternakan dan perikanan, dimana kandungan nutrisinya masih memadai untuk diolah menjadi pakan.

Bahan baku pakan harus memenuhi dua persyaratan yaitu secara teknis dan secara ekonomis. Secara teknis pakan harus memiliki kandungan semua nutrisi yang diperlukan oleh ayam, bahan baku harus yang mudah dicerna oleh ayam, bahan baku pakan tidak boleh cacat, tengik, berjamur, lembab, bergumpal, berbau dan palsu. Syarat ekonomisnya yaitu harga pakan tidak terlalu mahal sehingga peternak ayam masih mendapat keuntungan (Sudarmono: 2003).

Pakan ayam sebaiknya mengandung campuran bahan makanan yang berasal dari tumbuhan dan hewan. Alternatif penambahan vitamin, asam amino, energi dan mineral yang dapat dikombinasikan dalam pakan ayam adalah limbah cangkang telur dan keong sawah yang banyak terdapat disekitar lahan pertanian masyarakat. Cangkang telur dan keong sawah ini dapat digunakan sebagai campuran pakan pada pakan ternak. Penggunaan tepung tulang dan daging sangat penting untuk memenuhi pakan unggas, khususnya ayam karena nilai kandungan proteinnya tinggi (Bozkurt dkk. 2004). Penambahan tepung tulang dan daging dengan kosentrasi $5-10 \%$ dapat berpengaruh pada berat produksi telur dan pertambahan badan ayam.

Cangkang telur ayam merupakan bahan buangan dari sumber-sumber domestik seperti tempat pembenihan, peternakan unggas, pabrik produk telur, rumah, dan restoran. Banyak penelitian telah mencari cara untuk menggunakan limbah kulit telur, misalnya, dengan menggunakan bubuk cangkang telur sebagai bahan stabilisasi untuk memperbaiki sifat-sifat tanah (Amu O et al: 2005), sebagai sumber nutrisi untuk pakan babi (Schaafsma A. Beelen G. M: 1999), dan sebagai sumber nutrisi manusia (Schaafsma A : 1999). Selain itu, kulit telur yang diekstrusi, termasuk membran pada cangkang telur tersebut, dapat digunakan sebagai sumber nutrisi pada ayam tanpa menimbulakan efek buruk pada produksi telur (Hofstede G. J. H. Muskiet F. A. J. Van Der Veer E. De Vries P. J. E : 2000) menyatakan tidak ada efek 
merugikan pada berat telur, produksi telur, konversi pakan, dan gravitasi spesifik telur pada ayam petelur yang diberi makan yang mengandung makanan cangkang telur. Mengeringkan cangakng kulit telur pada suhu tinggi sangat penting, untuk mengurangi potensi kontaminasi oleh patogen.

Cangkang telur ayam terdiri dari membran dalam dan luar. Membran ini mempertahankan albumen dan mencegah penetrasi bakteri. Selaput kulit juga penting untuk pembentukan kulit telur. Bahan organik cangkang telur dan selaput kulit mengandung protein sebagai konstituen utama dengan sejumlah kecil karbohidrat dan lipid (Burley, R. W., and D. V. Vadehra : 1989). Secara umum struktur cangkang telur terdiri atas tiga lapisan, yaitu lapisan kutikula, lapisan spons, dan lapisan lamelar. Lapisan kutikula merupakan permukaan terluar yang mengandung sejumlah protein. Lapisan spons dan lamelar membentuk matriks yang dibentuk oleh serat protein yang terikat oleh kalsium karbonat dalam cangkng telur. Cangkang telur mewakili $11 \%$ dari total bobot telur dan tersusun oleh kalsium karbonat (94\%), kalsium fosfat (1\%), material organik (4\%), dan magnesium karbonat (1\%) (Rivera E.M.,et al. 1999).

Kandungan kalsium karbonat dari cangkang telur ayam yang dikeringkan dengan penempelan albumin dapat dilihat pada tabel di bawah ini:

Tabel 1. Komposisi nutrisi cangkang telur ayam yang dikeringkan dengan penempelan albumin.

\begin{tabular}{lc}
\hline \multicolumn{1}{c}{ Nutrisi } & Kandungan $(\%$ berat $)$ \\
\hline Air & $29-35$ \\
Protein & $1,4-4$ \\
Kalsium & $35,1-36,4$ \\
CaCO3 & 90,9 \\
Fosfor & 0,12 \\
Magnesium & $0,37-0,40$ \\
Kalium & $0,10-0,13$ \\
Sulfur & $0,09-0,19$ \\
Alanin & 0,45 \\
Arginin & $0,56-0,57$ \\
Asam aspartate & $0,83-0,87$ \\
Cistin & $0,37-0,41$ \\
Asam glutamate & $1,22-1,26$
\end{tabular}

\begin{tabular}{lc}
\hline \multicolumn{1}{c}{ Nutrisi } & Kandungan $(\%$ berat $)$ \\
\hline Glisin & $0,37-0,41$ \\
Histidin & $0,25-0,30$ \\
Isoleusin & 0,34 \\
Leusin & 0,57 \\
Lisin & 0,37 \\
Metionin & $0,28-0,29$ \\
Phenilalanin & $0,38-0,46$ \\
Prolin & $0,54-0,62$ \\
Serin & $0,64-0,65$ \\
Thereonin & $0,45-0,47$ \\
Tirosin & $0,25-0,26$ \\
Valin & $0,54-0,55$ \\
\hline Sumber : Ockerman P.A. 1981
\end{tabular}

Sumber : Ockerman,P.A. 1981

Selain cangkang telur ayam keong mas juga cukup potensial sebagai sumber protein hewani. Keong mas memiliki kandungan gizi lain yakni kalori dan karbohidrat. Keong mas juga mengandung vitamin dan mineral yang dibutuhkan oleh tubuh. Beberapa mineral yang ditemukan dalam daging keong mas antara lain kalsium, natrium, kalium, fosfor, magnesium, seng, dan zat besi. Tabel berikut menunjukkan kandungan mineral daging keong mas (Pambudi, N.D :2011).

Tabel 2. Kandungan mineral keong mas

\begin{tabular}{llll}
\hline $\begin{array}{c}\text { Komposisi } \\
\text { mineral } \\
\text { makro }\end{array}$ & $\begin{array}{c}\text { Kadar (bk) } \\
(\mathrm{mg} / 100 \mathrm{gr})\end{array}$ & $\begin{array}{c}\text { Komposisi } \\
\text { mineral } \\
\text { mikro }\end{array}$ & $\begin{array}{c}\text { Kadar (bk) } \\
(\mathrm{mg} / 100 \mathrm{gr})\end{array}$ \\
\hline Kalsium & 7593,81 & Besi & 44,16 \\
Natrium & 620,84 & Seng & 20,57 \\
Kalium & 824,84 & Selenium & Tidak terdeteksi \\
Fosfor & 1454,32 & Tembaga & Tidak terdeteksi \\
Magnesium & 238,05 & & \\
\hline
\end{tabular}

Komposisi kimia keong mas dinyatakan dalam persentase dari unsurunsur air, abu, protein, dan lemak. Komposisi kimia bahan baku sangat bervariasi, tergantung pada ukuran, kelamin, tingkat kematangan seksual, maupun waktu penangkapan biota. Komposisi kimia daging keong mas disajikan pada tabel berikut:

Tabel 3. Komposisi kimia keong mas

\begin{tabular}{lccc}
\hline $\begin{array}{l}\text { Komposisi } \\
\text { kimia }\end{array}$ & $\begin{array}{c}\text { Nurjanah et al } \\
(1996)\end{array}$ & $\begin{array}{c}\text { Susanto } \\
(2010)\end{array}$ & $\begin{array}{c}\text { Pambudi } \\
(2011)\end{array}$ \\
\hline Kadar air & $84,70(\mathrm{bb})$ & $81,19(\mathrm{bb})$ & $81,50(\mathrm{bb})$ \\
Kadar & $9,33(\mathrm{bb})$ & $10,30(\mathrm{bb})$ & $7,58(\mathrm{bb})$ \\
protein & & & \\
Kadar lemak & $0,91(\mathrm{bb})$ & $0,51(\mathrm{bb})$ & $2,10(\mathrm{bb})$ \\
Kadar abu & $1,43(\mathrm{bb})$ & $4,07(\mathrm{bb})$ & $9,03(\mathrm{bb})$ \\
\hline
\end{tabular}


Membuat pakan ternak yang mengandung cangkang telur dan keong mas harus menggunakan mesin. Mesin ini menggunakan sistem mekanis. Hasil dari mesin ini yaitu menghasilkan pakan yang bernilai gizi tinggi. Rancang bangun mesin ini dimulai dari perancangan dan prinsip kerja mesin tersebut.

Perancangan adalah kegiatan awal dari suatu kegiatan dalam proses pembuatan produk. Perancangan tersebut ditentukan dengan keputusan-keputusan penting dimana keputusan ini akan mempengaruhi kegiatan yang akan datang. Pelaksanaan perancangan ini mengacu dari pemanfaatan ilmu dasar teknik, hasil penelitian-penelitian terdahulu, informasi, teknologi, dan pengembangan serta kemajuan yang mutakhir (Sonawan :2010).

Prinsip kerja yang digunakan dalam perancangan mesin pengolahan limbah cangkang telur dan keong sawah antara lain:

A. Motor listrik setelah dihidupkan harus memiliki putaran dengan kecepatan $1450 \mathrm{rpm}$.

B. Putaran dari motor listrik akan menyebabkan pulley berputar dan sabuk transmisi menggerakkan gear pada gear box yang memiliki rasio 1:20.

C. Akibatnya poros mesin akan berputar dengan kecepatan $\pm 72,5 \mathrm{rpm}$.

D. Putaran poros akan memutar pengaduk yang terpasang pada poros.

E. Bahan-bahan yang dimasukkan kedalam mesin akan diaduk hingga tercampur.

Campuran-campuran ini akan dibentuk menjadi butiran-butiran kecil.

\section{METODE PENELITIAN}

\section{A. Rancangan Penelitian}

Pendekatan yang digunakan dalam penelitian ini adalah bersifat investigasi dan survei, yang dilaksanakan dengan teknik dan metode yang disesuaikan pada tujuan penelitian. Fish bone dari rancangan penelitian ini terlihat pada Gambar 1 .

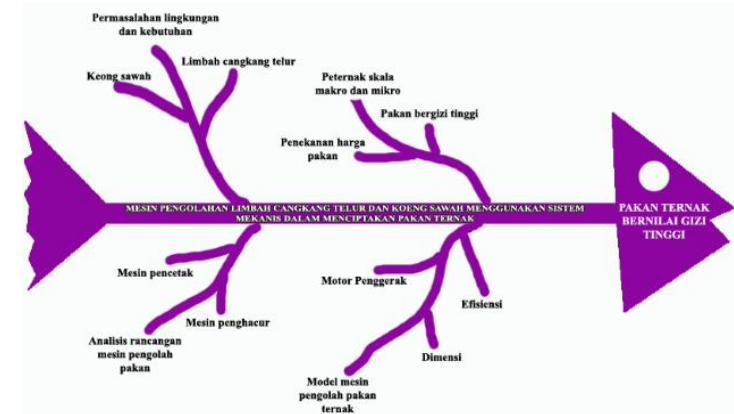

Gambar 1. Diagram Fish Bone

\section{B. Metode Pelaksanaan}

Tahapan pelaksanaan penelitian ini untuk sementara dirancang samapai pada pembuatan mesin pengolah pakan. Metode yang digunakan dalam penelitian ini adalah eksperimen. Indikator yang menjadi ukuran ada dua macam. Pertama adalah mesin pengolah pakan, yang kedua adalah kualitas pakan. Pada rancangan mesin yang menjadi target adalah efisensi secara finansial, efisiensi secara operasional dan efisiensi secara kuantitas. Para peternak skala mikro dan makro diharapkan dapat menggunakan mesin ini dalam mengolah pakan ternak sendiri. Untuk kualitas pakan, peneliti akan menguji kualitas pakan ini pada ahli bagian peternakan.

\section{HASIL DAN PEMBAHASAN}

Kegiatan penelitian dilaksanakan di workshop Fabrikasi Jurusan Teknik Mesin Fakutas Teknik Universitas Negeri Padang. Pelaksanaan kegiatan dimulai dengan membuat gambar rancang dari mesin pengolah pakan dan dilengkapi dengan ayakan. Fungsi dari rancangan ayakan ini adalah mesin pengolah pakan ini mampu membuat pakan untuk anakan ayam dan ayam yang sudah besar (pakan bubuk dan pakan butiran). Pembuatan rancangan menggunakan aplikasi Autocad versi 2008. Berikut design yang dihasilkan. 


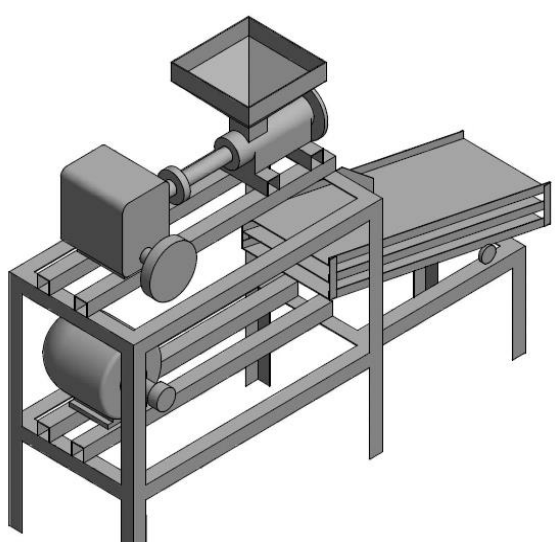

Gambar 2. Hasil Rancangan

A. Pembuatan Screw

Setelah gambar rancangan selesai maka proses pembuatan dilakukan. Komponen yang pertama dibuat adalah screw. Screw akan berfungsi bebagai pengantar dalam proses pencetakan. Daun screw dibuat menggunakan plat $4 \mathrm{~mm}$ dan poros screw menggunakan besi mildsteel ST37 dengan diameter $25 \mathrm{~mm}$. Setelah screw selesai makan dibuat bodi screw dengan menggunakan pipa dengan diameter 6 inchi dengan ketebalan $5 \mathrm{~mm}$.
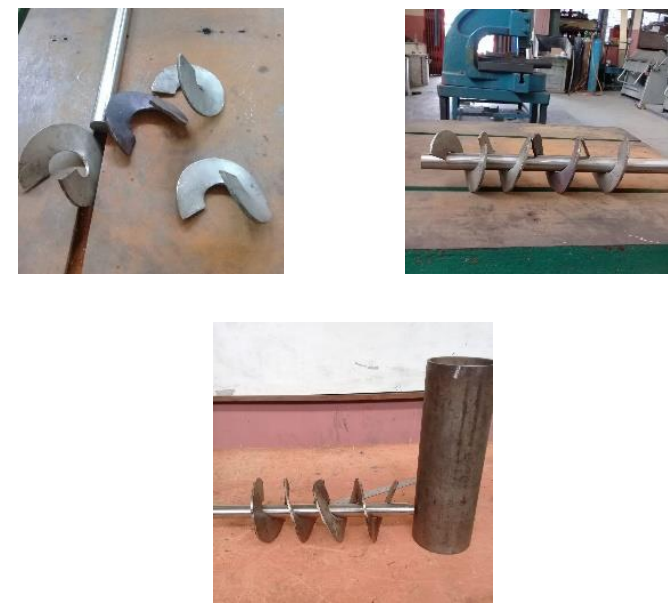

Gambar 3. Proses Pembuatan Screw

\section{B. Pembuatan Saringan Cetak}

Selanjutnya pembuatan saringan cetak, untuk saringan cetak menggunakan besi plat dengan ketebalan $15 \mathrm{~mm}$. pengerjaan cetakan ini mengunakan mesin bubut. Setelah dibubut maka dibuat lubanglubang kecil dengan diameter $3 \mathrm{~mm}$ sebanyak mungkin. Pada ujung cetakan tercapat pisau pemotong dengan tiga pisau yang dibautkan keporos. Pisau ini akan memotong hasil pakan yang keluar dari cetakan sehingga hasil pakan berbentuk butiran-butiran kecil.
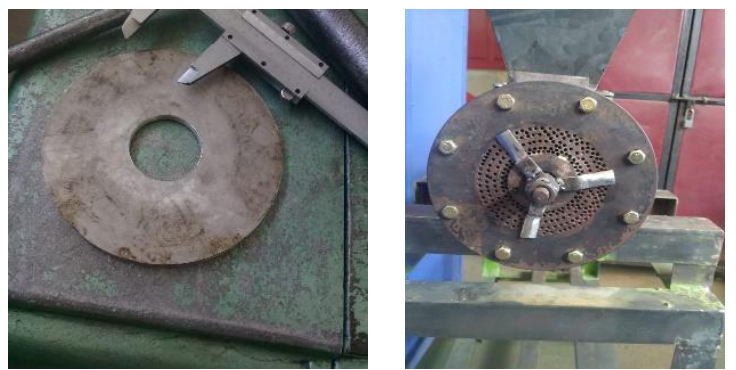

Gambar 4. Proses Pembuatan Bakal Cetakan Pakan

\section{Pembuatan Rangka}

Rangka utama pada mesin pencetak pakan ini dibuat menggunakan besi siku 40 $\mathrm{x}$ 40. Sedangkan untuk penyangga digunakan bahan dari besi U 50. Rangkan dirangkai dengan menggunakan las sesuai dengan rancangan yang telah dibuat.

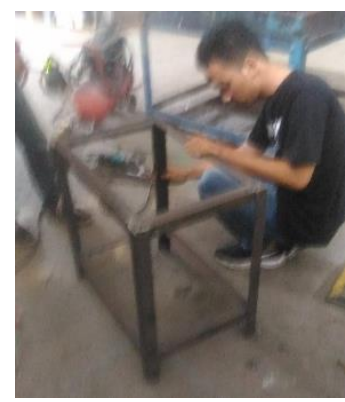

Gambar 5. Proses Pembuatan Rangka

D. Pembuatan Komponen Ayakan

Komponen ayakan pada mesin penceatak pakan ini berfungsi sebagai pemisah antara hasil yang berbentuk serbuk dan hasil yang berbentuk butiran. Pemisahan ini bertujuan untuk memilah pakan yang bias digunakan untuk anakan ayam dan pakan yang bias digunakan untuk ayam yang sudah besar. Ayakan terdiri dari tiga tingkatan dengan besar ram penyaring yang bervariasi. Rangka dari ayakan dibuat dari besi siku $25 \times 25 \mathrm{~mm}$. ram pada ayakan dipasang dengan menggunakan paku rivet. Ayakan digerakkan dengan menggunakan pegas yang dipasang pada bagian bawah ayakan dengan penggerak bergantung pada poros mesin pencetak pakan. 

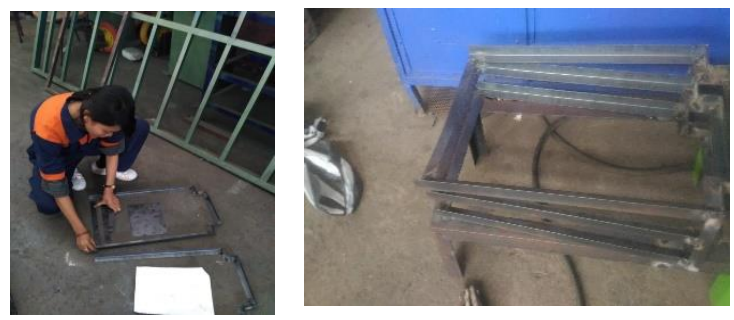

Gambar 6. Proses Pembuatan Ayakan

Proses pembuatan alat cetak pakan ini pada saat ini telah sampai pada proses finising. Secara operasional mesin ini sudah diuji namun untuk pengambilan data penelitian belum dilakukan. Berikut gambar kondisi finising pada mesin pencetak pakan.
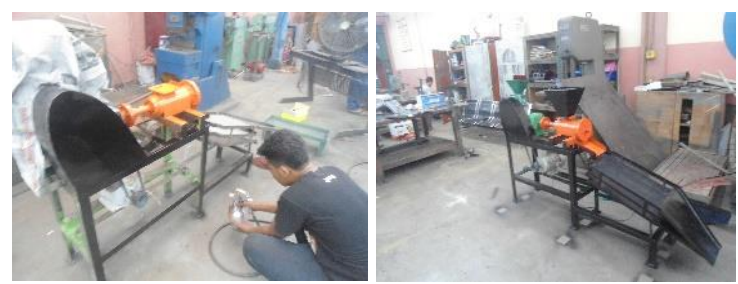

Gambar 7. Proses Finising

\section{E. Hasil Pelaksanaan \\ 1. Spesifikasi alat}

Mesin pencetak pakan ayam yang dibuat menggunakan motor listrik dengan daya 1 HP rotasi $2800 \mathrm{rpm}$ dan reducer dengan konversi putaran 1:30. Selain itu, mesin ini juga menggunakan diskmild sebagai penghancur dari konsetrat yang digunakan. diskmild digerakan dengan menggunakan motor yang sama. Sehingga motor yang digunakan ini menggerakkan dua buah mesin sekaligus.

2. Uji kinerja mesin pengolah cangkang telur dan keong sawah

Hasil uji kinerja mesin dilakukan sebanyak 5 kali pengulangan dengan berat bahan baku yang digunakan sebanyak 1 kg. Perhitungan kapasistas pencetakan dihitung dengan rumus:

1) $\frac{\text { berat ransum terbentuk }(\mathrm{kg})}{\text { waktu yang dibutuhkan }(\mathrm{jam})}=\frac{0,91}{0,059}=15,42$
2) $\frac{\text { berat ransum terbentuk }(\mathrm{kg})}{\text { waktu yang dibutuhkan (jam) }}=\frac{0,92}{0,058}=15,86$

3) $\frac{\text { berat ransum terbentuk }(\mathrm{kg})}{\text { waktu yang dibutuhkan }(\mathrm{jam})}=\frac{0,93}{0,057}=16,32$

Tabel 4. Hasil uji kinerja mesin

\begin{tabular}{ccccc}
\hline No & $\begin{array}{c}\text { Berat } \\
\text { bahan } \\
\text { awal }(\mathrm{kg})\end{array}$ & $\begin{array}{c}\text { Waktu } \\
\text { (jam) }\end{array}$ & $\begin{array}{c}\text { Berat bahan } \\
\text { akhir }(\mathrm{kg})\end{array}$ & $\begin{array}{c}\text { Kapasitas } \\
(\mathrm{kg} / \mathrm{jam})\end{array}$ \\
\hline 1 & 1 & 0,059 & 0,91 & 15,42 \\
2 & 1 & 0,058 & 0,92 & 15,86 \\
3 & 1 & 0,057 & 0,93 & 16,32 \\
& Rata-rata & 0,058 & 0,92 & 15,86 \\
\hline
\end{tabular}

Berdasarkan hasil uji kinerja mesin pengolahan cangkang telur dan keong sawah sebanyak 3 kali pada tabel 1, maka kapasitas yang dihasilkan mesin sebesar $15,86 \mathrm{~kg} / \mathrm{jam}$.

Bahan baku yang tidak tercetak dihitung persentasenya dengan persamaan yaitu:

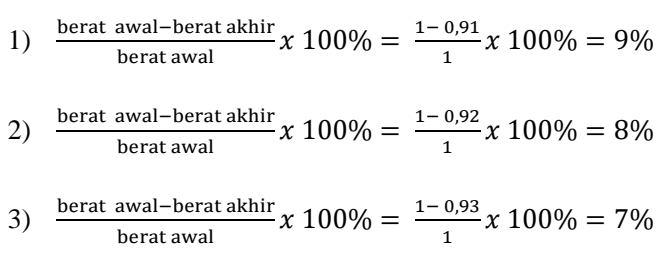

Tabel 5. Hasil yang tidak tercetak

\begin{tabular}{cccc}
\hline No & $\begin{array}{c}\text { Berat bahan } \\
\text { awal (kg) }\end{array}$ & $\begin{array}{c}\text { Berat bahan } \\
\text { akhir }(\mathrm{kg})\end{array}$ & $\begin{array}{c}\text { Persentase } \\
\text { yang tidak } \\
\text { tercetak (\%) }\end{array}$ \\
\hline 1 & 1 & 0,91 & 9 \\
2 & 1 & 0,92 & 8 \\
3 & 1 & 0,93 & 7 \\
& Rata-rata & 0,92 & 8 \\
\hline
\end{tabular}

Data yang didapat dari 3 kali uji kinerja maka bahan yang tidak bisa dicetak atau tidak hancur mendekati $8 \%$, karena rancangan bahan terbuat dari besi dengan tingkat kekerasan sedang sehingga menyebabkan ada bahan yang menempel, namun bahan masih dapat dicetak ulang dengan cara memasukkan ke mesin kembali.

\section{Hasil pakan}

Hasil dari kinerja mesin tersebut juga menghasilkan 3 macam tingkatan pakan. Pakan yang berbentuk serbuk, halus dan kasar. Hasil pakan tersebut dapat dilihat pada tabel 6 berikut ini. 
Tabel 6. Hasil pakan yang dihasilkan

\begin{tabular}{ccccc}
\hline \multirow{2}{*}{ No } & $\begin{array}{c}\text { Berat } \\
\text { bahan } \\
\text { awal }(\mathrm{kg})\end{array}$ & $\begin{array}{c}\text { Serbuk } \\
(\mathrm{kg})\end{array}$ & Halus $(\mathrm{kg})$ & Kasar $(\mathrm{kg})$ \\
\cline { 3 - 5 } 1 & 1 & 0,2275 & 0,3725 & 0,31 \\
2 & 1 & 0,2346 & 0,3735 & 0,3119 \\
3 & 1 & 0,2347 & 0,3789 & 0,3164 \\
& Rata-rata & 0,2323 & 0,3749 & 0,3128 \\
\hline
\end{tabular}

Berdasarkan tabel 3, maka hasil pakan yang berbentuk serbuk yang dihasilkan dengan bahan baku awal $1 \mathrm{~kg}$ adalah $0,2323 \mathrm{~kg}$, pakan yang berbentuk halus adalah $0,3749 \mathrm{~kg}$, dan pakan yang berbentuk kasar adalah $0,3128 \mathrm{~kg}$.

\section{F. Pembahasan}

Pakan ayam yang dibuat dari rancangan mesin ini terdiri dari cangkang ayam dan keong sawah yang telah dikeringkan terlebih dahulu. Proses pengeringan dari cangkang ayam dan keong sawah ini dilakukan selama 3 hari. Terlihat pada gambar 8 .

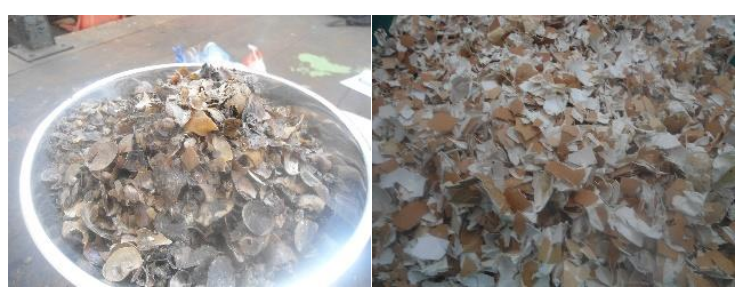

Gambar 8. Keong sawah dan cangkang telur yang telah dikeringkan

Mesin pencetak pakan ayam ini menggunakan dua buah mesin. Mesin yang pertama merupakan mesin penghasil serbuk. Mesin ini mengubah cangkang keong dan cangkang telur menjadi serbuk. Terlihat pada Gambar 9.

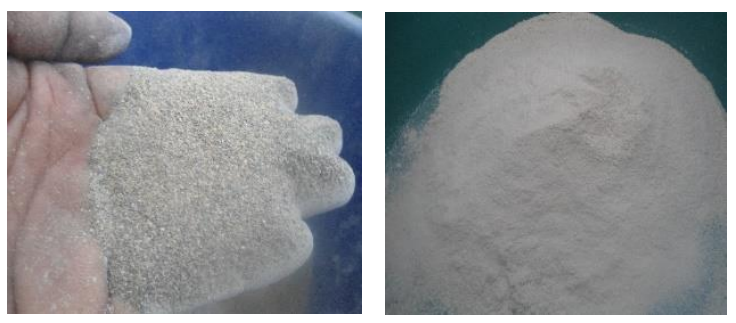

Gambar 9. Serbuk dari cangkang keong dan cangkang telur
Setelah bahan telah menjadi serbuk, bahan tersebut akan masuk kedalam mesin pembentuk pelet. Keong sawah dan cangkang telur tersebut dicampur dengan dedak dengan perbandingan 1: 1:8. Pencampuran ditambahkan dengan tepung tapioka, tepung tapioka berfungsi untuk pelengketan bahan.

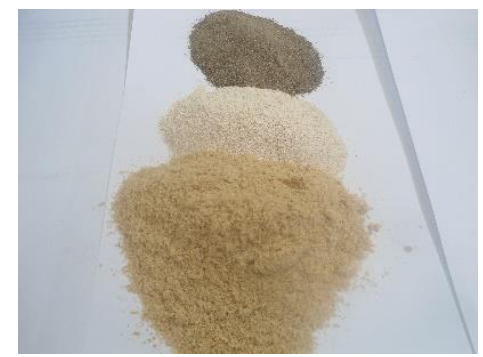

Gambar 10. Bahan-bahan yang digunakan dalam pembuatan pakan ayam

Semua bahan yang telah dicampur tersebut, dimasukkan ke dalam mesin pembuat pakan ayam secara bertahap. Pakan ayam yang dihasilkan terdiri dari tiga macam yaitu yang berbentuk serbuk, halus dan kasar terdapat pada gambar 11 .

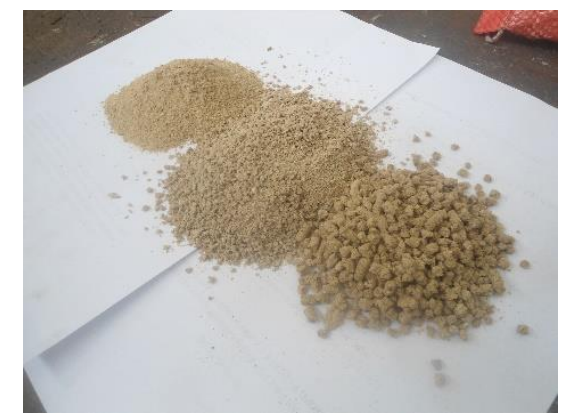

Gambar 11. Hasil pengolahan pakan ayam

\section{KESIMPULAN}

Kesimpulan yang dihasilkan dalam penelitian ini adalah:

A. Dalam penelitian ini, peneliti membuat mesin pencetak pakan dengan menggunakan mekanisme screw dengan daya motor penggerak $1 \mathrm{HP}$ dengan rotasi $2800 \mathrm{rpm}$ dan reducer dengan konversi putaran 1:30. Selain itu, mesin ini juga menggunakan diskmild sebagai penghancur dari konsetrat yang digunakan. diskmild digerakan dengan menggunakan motor yang sama. Sehingga motor yang digunakan ini 
menggerakkan dua buah mesin sekaligus.

B. Kapasitas uji kinerja mesin pengolahan cangkang telur dan keong sawah sehingga terbentuknya pakan sebesar $15,86 \mathrm{~kg} / \mathrm{jam}$ dan persentase bahan yang tidak tercetak yaitu $8 \%$.

C. Hasil pakan yang berbentuk serbuk yang dihasilkan dengan bahan baku awal $1 \mathrm{~kg}$ adalah $0,2323 \mathrm{~kg}$, pakan yang berbentuk halus adalah $0,3749 \mathrm{~kg}$, dan pakan yang berbentuk kasar adalah $0,3128 \mathrm{~kg}$.

D. Lubang pencetak dibuat menggunakan bor $3 \mathrm{~mm}$, besar lubang ini di anulir cocok untuk menghasilkan pakan yang bervariasi ukurannya.

Mesin pencetak pakan ayam ini menggunakan tiga tingkatan ayakan yang bertujuan untuk memisahkan pakan yang digunakan untuk ayam anakan dan ayam yang sudah besar..

\section{DAFTAR PUSTAKA}

http://sdp2d.sumbarprov.go.id/data_profil/ html 2print/171/0/2/2012-2016).

Suprijatna. 2008. Ilmu Dasar Ternak Unggas. Penebar Swadaya. Jakarta.

Sudarmono, A.S. 2003. Pedoman Pemeliharaan Ras Petelur. Jakarta: Kanisius.

Bozkurt dkk. 2004. Effect of Dietary Concentration Meat and Bone Meal on Broiler Chickens Performance. International Journal of Poultry Science, 3 (11): 719-723.

Amu O. O. Fajobi A. B. Oke B. O. 2005. Effect of Eggshell Powder On The Stabilizing Potential Of Lime On An Expansive Clay Soil. Res. J. Agric. \& Biol. Sci. 1: 80-84

Schaafsma A. Beelen G. M. 1999. Eggshell Powder, A
Comparable Or Better Source Of Calcium Than Purified Calcium Carbonate: Piglet Studies. J. Sci. Food Agric. 79: 1596-1600.

Schaafsma A. 1999. Effect of A Chicken Egg Shell Powder Enriched Dairy Product On Bone Mineral Density In Persons With Osteoporosis Or Osteopenia. Nutrition 15: 157

Hofstede G. J. H. Muskiet F. A. J. Van Der Veer E. De Vries P. J. E. 2000. Mineral, Amino Acid, And Hormonal Composition Of Chicken Eggshell Powder And The Evaluation Of Its Use In Human Nutrition. Poult. Sci. 79: 1833-1838..

Froning G. W. Bergquist D. 1990. Utilization Of Inedible Eggshells And Technical Albumen Using Extrusion Technology. Poult. Sci. 69: 2051-2053.

Tadtiyanant C. Lyons J. J. Vandepopuliere J. M. 1993. Extrusion Processing Used To Convert Dead Poultry, Feathers, Eggshells, Hatchery Waste, And Mechanically Deboned Residue Into Feedstuffs For Poultry. Poult. Sci. 72: 1515-1527.

Burley, R. W., and D. V. Vadehra. 1989. The Egg Shell And Shell Membranes: Properties And Synthesis. Pages 25-64 in The Avian Egg, Chemistry and Biology. John Wiley, New York.

Rivera E.M.,et al. 1999. Synthesis of Hydroxiapatite from Eggshells. Material Letters. $41: 128-134$.

Ockerman,P.A. 1981. Nutrient Intake And Health Status Of Vegans: Chemical Analyses Of Diets Using The Duplicate Portion Sampling Technique - Am J Clin Nutr, 34 November ,pp.2464-2477. 
Pambudi, N.D. 2011. Pengaruh Metode Pengolahan Terhadap Kelarutan Mineral Keong Mas (Pomacea Canaliculata) dari Perairan Situ Gede. ITB.

Sonawan. 2010. Perancangan Elemen Mesin. Alfabeta: Bandung. 